\title{
Strategi Pembinaan dan Pendampingan Koperasi Peternak Sapi Perah Dalam Mendukung Keberlangsungan Koperasi dan Ketahanan Ekonomi Anggota (Studi Di KUD Sinar Jaya)
}

\author{
Apriwandi $^{*}$, Aida Wijaya ${ }^{2}$, R. Wedi Rusmawan Kusumah ${ }^{3}$, Andina Nur \\ Fathonah $^{4}$, Erly Sherlita ${ }^{5}$, Achmad Fadjar6, Ibnu Rachman ${ }^{7}$, Rachmat \\ Hidayat $^{8}$ \\ 1, 2, 3, 4, 5, 6, 7, ${ }^{8}$ Universitas Widyatama, Indonesia \\ *e-mail: apri.wandi@widyatama.ac.id
}

\begin{abstract}
The purpose of this study to examine the use of mentoring and coaching strategies in dairy farmer cooperatives as a means of improving cooperative performance. at this time, cooperatives must survive and maintain the success of their organizations at the highest level because of the high expectations of cooperative stakeholders. This research was conducted in the internal management of the KUD Sinarjaya cooperative involving 105 members and management of the cooperative as respondents. Observations were carried out during coaching and mentoring in the first week of April 2020. Primary and secondary data from the KUD Sinarjaya cooperative, dairy business unit and livestock unit were analyzed using descriptive analysis. The research findings show that the problems in cooperative management and accounting have not been achieved as their best. Most of the accounting staff do not understand the accounting process and in the end the financial reports are not sufficient to meet the needs of cooperative users. This research focuses on assisting the accounting process and cooperative management as a support activity for cooperative activities, which will be a source of motivation and an effective performance booster not only for cooperatives but also for management and staff.
\end{abstract}

Keywords: mentoring, coaching, performance, dairy farmers

\begin{abstract}
Abstrak: Tujuan penelitian ini untuk mengetahui pemanfaatan strategi pendampingan dan pembinaan pada koperasi peternak sapi perah sebagai sarana peningkatan kinerja koperasi. Saat ini koperasi harus dapat bertahan dan mempertahankan kesuksesan organisasinya pada level tertinggi karena harapan yang tinggi dari stakeholders koperasi. Penelitian ini dilakukan pada pengurus internal koperasi KUD Sinarjaya dengan melibatkan 105 anggota dan pengurus koperasi sebagai responden. Pengamatan dilakukan pada saat pembinaan dan pendampingan pada minggu pertama April 2020. Data primer dan sekunder dari koperasi KUD Sinarjaya, unit usaha susu dan unit ternak dianalisis menggunakan analisis deskriptif. Hasil penelitian menunjukkan bahwa permasalahan dalam manajemen dan akuntansi koperasi belum dapat diselesaikan dengan sebaik-baiknya. Sebagian besar staf akuntansi kurang memahami proses akuntansi dan pada akhirnya laporan keuangan tersebut tidak mencukupi untuk memenuhi kebutuhan pengguna koperasi. Penelitian ini difokuskan pada pendampingan proses pembukuan dan pengurus koperasi sebagai penunjang kegiatan koperasi, yang nantinya akan menjadi sumber motivasi dan pendorong kinerja yang efektif tidak hanya bagi koperasi tetapi juga bagi pengurus dan pegawai.
\end{abstract}

Kata Kunci: Pendampingan, pembinaan, kinerja, peternak sapi perah 


\section{PENDAHULUAN}

Koperasi merupakan organisasi demokratis dan orientasi ekonomi rakyat yang berkontribusi secara signifikan terhadap integrasi sosial, penciptaan lapangan pekerjaan dan pengentasan kemiskinan (Castilla-Polo \& Sánchez-Hernández, 2020; Harelimana, 2020; Velmonte, 2020). Berbagai jenis bidang kegiatan koperasi yang menyesuaikan ekonomi, misalnya koperasi peternakan, pertanian, perikanan dan perkebunan. Khususnya dalam penelitian ini memfokuskan pada koperasi peternakan sapi perah dari sudut pandang ekonomi, sosial dan lingkungan. Dengan demikian, mempertahankan koperasi peternakan sapi perah adalah menstabilkan siklus ekonomi regional dan meningkatkan penyerapan tenaga kerja di lingkungan sekitar koperasi.

Perubahan iklim perkoperasian dalam perubahan yang cepat dan evolusi akibat krisis ekonomi yang masih memengaruhi proses kegiatan koperasi di Indonesia. Perubahan cepat ini menjadi momentum bagi koperasi untuk memulai lagi mengembangkan dirinya dengan cara dan strategi yang tepat, bahkan jika diperlukan dengan strategi dan cara berbeda dari masa sebelumnya. Sampai saat ini koperasi masih tetap diharapkan membentengi masyarakat dari kesulitan yang timbul oleh krisis ekonomi global. Walaupun tidak semua masyarakat yang memahami bahwa koperasi soko guru perekonomian, prakteknya koperasi tidak lebih maju daripada badan usaha lainnya (Zulhartati, 2010).

Agar koperasi dapat terus eksis, maka koperasi dituntut untuk selalu dapat meningkatkan efektivitas kinerja koperasi yang harus dilakukan oleh pengurus, karyawan dan pengawas koperasi secara optimal dengan melihat peluang-peluang yang dimiliki oleh koperasi yang dapat mewujudkan tujuannya yaitu meningkatkan kesejahteraan anggotanya. Proses pendampingan banyak dilakukan organisasi untuk melatih, mengembangkan dan memotivasi karyawan dalam mencapai tujuan organisasi (Roubitchek, 2018; My Coop, 2017; Yirci et al., 2016). Peran Pembelajaran dari lembaga akademis dan pelatihan dalam pengembangan koperasi adalah untuk mengajar, melatih dan membimbing orang tentang bagaimana model koperasi berfungsi dalam konteks yang berbeda dan bagaimana model tersebut dapat berkontribusi untuk memenuhi kebutuhan ekonomi dan sosial (Taremwa \& Lopoyetum, 2015). 
Pembinaan digambarkan sebagai sarana yang untuk mengembangkan dan keterampilan dalam manajemen organisasi. Tujuan utama dari pembinaan ini menciptakan hubungan pembelajaran yang sehat untuk meningkatkan kinerja dan pengembangan individu yang memberikan dampak terhadap aktivitas organisasi yang efektif dan efisien (Kilburg, 2000; Yirci et al., 2016). Untuk alasan ini, banyak perusahaan menginvestasikan dananya untuk pembinaan setiap tahun yang melibatkan dunia akademis atau universitas dalam membina dan mendampingi dalam memperbaiki tata kelola organisasi.

Langkah yang digunakan untuk mewujudkan badan usaha yang sehat dan berdaya saing tinggi, diperlukan pendekatan dalam meningkatkan kompetensi SDM koperasi. Langkah tersebut dapat berupa pembinaan dan pendampingan terencana, terpadu, dan dikoordinasikan dengan melibatkan pihak universitas dan meningkatkan sinergitas antara koperasi dan stakeholder. Namun demikian, proses manajemen internal koperasi yang tidak terstandar dan bahkan menyimpang dari prosedur manajemen seharusnya.

Hal ini disebabkan peran dari pihak akademisi dan universitas, serta pemerintah dalam merespon fenomena yang terjadi di internal koperasi. Serta eksistensi koperasi berpayung pada hukum dan berkaitan dengan kondisi sosial anggota masyarakat (Nasution \& Thamrin, 2016; Sulistia \& Suparman, 2019). Pembinaan dapat berdampak signifikan pada organisasi dan karyawan bila diterapkan secara efektif. Wilson (2007) telah mengidentifikasi 7 prinsip untuk proses pembinaan yang efektif. Prinsip-prinsip ini diilustrasikan pada Gambar 1.

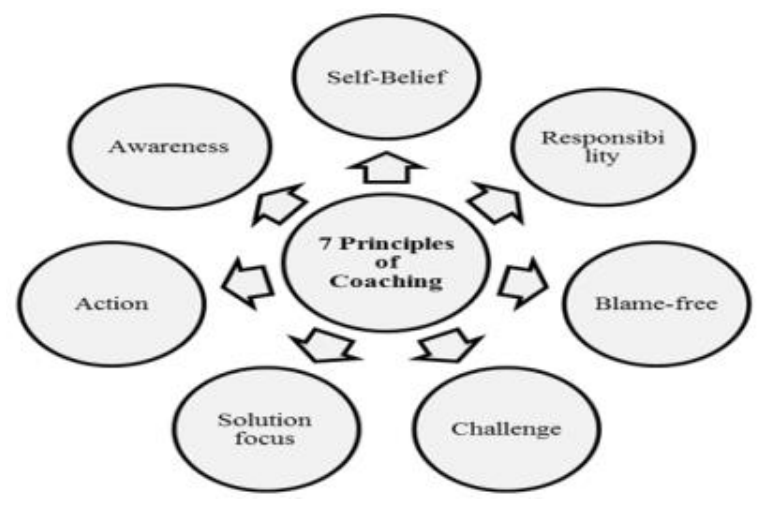

Gambar 1 Tujuh prinsip pembinaan

Sumber: (Wilson, 2007; Yirci et al., 2016)

Koperasi (KUD) Sinar Jaya adalah satu koperasi peternak sapi perah yang memproduksi susu sapi mentahan yang terletak Kecamatan Panyileukan, Kota 
Bandung, Provinsi Jawa Barat. KUD Sinar Jaya menjalankan usahanya sebagai koperasi susu dan selain kegiatan utama membuka unit-unit usaha seperti unit penyediaan pakan, unit simpan pinjam dan unit kesehatan. Pada tahun 2008, KUD Sinar Jaya sempat mengalami kondisi yang tidak cukup baik dalam manajemen menyebabkan aktivitas terhenti sampai awal tahun 2011.

Tujuan penelitian ini untuk mengetahui dan menguji peran pembinaan dan pendampingan pegawai dalam meningkatkan kinerja pegawai pada koperasi KUD Sinarjaya Ujung berung. Motivasi penelitian ini berdasarkan fenomena berhentinya kegiatan KUD Sinar Jaya sangat menarik untuk dilakukan penelitian tentang bagaimana peran strategi pembinaan dan pendampingan koperasi dalam mendukung ketahanan koperasi dan peningkatan ekonomi anggota koperasi.

\section{METODE}

Metode penelitian ini adalah "metode campuran" mengacu pada metodologi penelitian yang muncul yang memajukan integrasi sistematis, atau "pencampuran," data kuantitatif dan kualitatif dalam satu penyelidikan. Premis dasar dari metodologi ini adalah bahwa integrasi tersebut memungkinkan pemanfaatan data yang lebih lengkap dan sinergis daripada pengumpulan dan analisis data kuantitatif dan kualitatif yang terpisah (Creswell \& Plano Clark, 2011; Wisdom \& Creswell, 2013) dan menjelaskan fenomena sosial melalui pengamatan langsung pada objek penelitian (Sugiyono, 2018).

Penelitian ini mengidentifikasi permasalahan dalam tata kelola dan akuntansi koperasi dengan mengobservasi faktor-faktor yang mempengaruhi perkembangan koperasi serta strategi pemberdayaan KUD Sinar Jaya dalam mendukung keberlangsungan koperasi dan ketahanan ekonomi keluarga anggota. Observasi dilaksanakan langsung pada saat pelakanaan pembinaan dan pendampingan pada manajemen koperasi pada bulan April 2021. Lokasi penelitian ini adalah KUD Sinar Jaya, Ujung Berung, Kota Bandung. Lokasi tersebut diharapkan dapat mendulang data primer yang dihasilkan dari teknik observasi partisipan dan wawancara.

Penelitian ini menggunakan teknik pengumpulan data yang meliputi observasi partisipan, wawancara, dokumentasi, dan studi pustaka. Teknik analisis data gabungan antara teknik analisis data kuantitatif dan deskriptif kualitatif. Data yang diperoleh selama penelitian langsung dianalisis dan terus di cek kebenarannya 
pada pihak-pihak lain (cross check). Data mengenai faktor-faktor yang mempengaruhi perkembangan koperasi diperoleh dari anggota koperasi (responden).

\section{HASIL DAN PEMBAHASAN}

\section{Kinerja Koperasi}

Hasil pengukuran kinerja perusahaan mengadopsi Balanced Scorecard memenuhi beberapa kebutuhan manajerial dalam pengukuran kinerja melalui 4 perspektif ukuran dalam kartu skor:

a. Perspektif Keuangan: Pengukuran kinerja keuangan dengan menggunakan rasio profitabilitas yang berupa profit margin, dimana nilai profit margin pada tahun 2018 adalah 1,94\%, sedangkan pada tahun 2019 dan 2020 tidak ada keuntungan yang dihasilkan.

b. Perspektif Pelanggan: Masalah pelanggan cenderung terbagi dalam empat pendekatan yang meliputi waktu arus produk, kualitas produk, kinerja dan layanan pasca-jual, dan biaya. Lead time mengukur kemampuan koperasi dalam jumlah waktu yang dibutuhkan untuk memenuhi kebutuhan pelanggannya. Indeks CR tahun $2005=103.12 \%$, nilai ini lebih besar dari yang ditargetkan yaitu $100 \%$, dengan peningkatan sebesar $8.06 \%$ dari tahun sebelumnya. Indeks CA tahun $2005=57.14 \%$, nilai ini lebih kecil dari yang ditargetkan yaitu $100 \%$, dengan penurunan sebesar $25.91 \%$ dari tahun sebelumnya. Nilai rata-rata total Servqual (TSQ) saat ini adalah -6.58, dengan rata-rata nilai servqual (SKij) setiap dimensi kualitas adalah: -0.51, -1.09, 1.794, -1.891 dan -1.297, nilai ini menunjukkan anggota merasa tidak puas, karena bila nilai TSQ negatif $(<0)$ dikatakan "tidak memuaskan"

c. Perspektif Proses Bisnis Internal: perspektif ini diterjemahkan ke dalam ukuran mengenai aktivitas internal yang dilakukan koperasi untuk memenuhi harapan pelanggannya. Manajer atau pengurus koperasi memfokuskan pada operasi internal penting yang terkait pemenuhan kebutuhan pelanggan dan anggota. Kinerja KUD Sinarjaya unit peternakan pada perspektif ini kurang baik, karena pada tahun 2004 dan 2005 tidak terdapat pengadaan, pembelian, perluasan sarana dan prasarana unit bisnis seperti yang sering dilakukan pada tahun 
sebelumnya serta mengalami penurunan pendapatan secara berturut-turut, yaitu pada tahun 2004 dan tahun 2005 .

d. Perspektif Pembelajaran dan Pertumbuhan: ukuran ini terkait kemampuan inovasi, dan beradaptasi dengan lingkungan dan nilai koperasi. Artinya, kemampuan koperasi untuk meluncurkan produk baru dalam menciptakan nilai bagi pelanggan, dan meningkatkan efisiensi operasi, dan margin - tumbuh dan nilai anggota koperasi. Dalam perspektif ini dapat diketahui bahwa pekerja/karyawan KUD unit peternakan dinilai cukup puas dengan pekerjaannya, hal ini dapat dilihat dari hasil kuesioner yang menunjukkan angka sebesar $76.67 \%$, angka tersebut merupakan penilaian responden internal terhadap variabel kepuasan kerja yang ada pada kuesioner internal. Akan tetapi produktivitas dari pekerja sangatlah kurang, ini ditunjukkan dengan tidak adanya keuntungan yang didapat pada tahun 2019 dan 2020, sehingga tidak ada laba/sisa hasil usaha yang dihasilkan. Untuk kapabilitas sistem informasi dirasakan cukup baik, karena KUD selalu melakukan perbaikan serta peningkatan yang disesuaikan dengan kebutuhan.

Berdasarkan pengukuran ini, hasil kinerja yang dilakukan oleh KUD Sinarjaya pada tahun 2019 dan 2020 sangatlah kurang baik. Hal ini terlihat dari keempat perspektif/aspek yang telah diukur banyak mengalami penurunan. Untuk itu KUD Sinarjaya khususnya Unit Peternakan harus melakukan perbaikan secara berkesinambungan baik secara finansial maupun non finansial.

\section{Kinerja Pengurus Koperasi}

Kinerja Pengurus Koperasi tahun 2009 - 2011 menunjukan kinerja yang cukup baik akan tetapi masih kurang maksimal jika dilihat dari hasil perolehan sisa hasil usaha koperasi, data sekunder Puskop menunjukkan penurunan sisa hasil usaha, namun data sekunder tersebut belum cukup membuktikan kinerja pengurus koperasi. Untuk mengetahui tingkat kinerja pengurus koperasi, peneliti juga menanyakan kepada anggota melalui kuesioner disamping wawancara dengan salah satu pengurus koperasi dan satu orang anggota koperasi. Hasil jawaban tentang kinerja dari pengurus koperasi dapat dilihat pada tabel 1, sebagai berikut: 
Tabel 1 Kinerja Pengurus Koperasi

\begin{tabular}{|c|c|c|c|c|c|}
\hline \multirow[t]{2}{*}{ Pertanyaan } & \multicolumn{5}{|c|}{ Jawaban responden } \\
\hline & $\mathrm{Ya}$ & $\%$ & Tidak & $\%$ & $\mathrm{~N}$ \\
\hline $\begin{array}{l}\text { Apakah kinerja pengurus koperasi sudah cukup } \\
\text { baik? }\end{array}$ & 62 & 59 & 43 & 41 & 105 \\
\hline $\begin{array}{l}\text { Apakah usaha yang dilakukan pengurus koperasi } \\
\text { sudah mengalami peningkatan dari jenis usaha } \\
\text { utama maupun pelayanan? }\end{array}$ & 60 & 57 & 45 & 43 & 105 \\
\hline $\begin{array}{l}\text { Apakah selama kepengurusan koperasi terdapat } \\
\text { laporan pertanggungjawaban yang dilakukan } \\
\text { oleh pengurus koperasi yang diterima anggota? }\end{array}$ & 22 & 21 & 83 & 79 & 105 \\
\hline $\begin{array}{l}\text { Apakah pengurus selalu mensosialisasikan setiap } \\
\text { kebijakan yang dibuat pengurus? }\end{array}$ & 99 & 94 & 6 & 6 & 105 \\
\hline $\begin{array}{l}\text { Apakah pengurus koperasi menyampaikan } \\
\text { laporan keuangan dan menjelaskan secara detail } \\
\text { ke anggota? }\end{array}$ & 12 & 11 & 93 & 89 & 105 \\
\hline $\begin{array}{l}\text { Apakah SHU koperasi selalu memberikan } \\
\text { dampak pada ekonomi anggota? }\end{array}$ & 5 & 4,8 & 100 & $\begin{array}{l}95, \\
2\end{array}$ & 105 \\
\hline $\begin{array}{l}\text { Apakah pengurus menjelaskan besaran SHU } \\
\text { yang dibagikan setiap tahun? }\end{array}$ & 85 & 81 & 20 & 19 & 105 \\
\hline
\end{tabular}

Tabel 1 menyajikan kinerja pengurus KUD Sinarjaya adalah cukup baik. Analisis ini berdasarkan hasil respon dari para anggota koperasi dalam menilai kinerja dan pelayanan pengurus koperasi. Berdasarkan observasi dari data kuesioner menunjukkan rerata $50 \%$ memberikan respon yang baik atas kinerja dan pelayanan koperasi. Sesuai dengan RAT tahun 2011-2020 mengalami penurunan sisa hasil usaha. Meskipun demikian, penurunan tidak berpengaruh terhadap kinerja pengurus koperasi. Hal ini berarti jawaban responden sesuai dengan hasil RAT Koperasi. Berdasarkan wawancara dengan pengurus koperasi mengatakan bahwa: "Sebagian pengurus koperasi belum dibekali dengan pendidikan perkoperasian, tata kelola koperasi dan bahkan akuntansi koperasi. Selain itu, ketua pengurus lebih memahami semua aktifitas manajemen, staf sedikit memahami aktivitas manajemen koperasi. Hal menjadi kendala bagi peneliti dalam 
melaksanakan tugas sebagai pengurus koperasi dan memenuhi harapan yang dituangkan dalam edaran dinas koperasi provinsi.

\section{Faktor-faktor yang mempengaruhi perkembangan Koperasi}

a. Faktor-faktor Pengelolaan Keuangan dan Akuntansi Internal Koperasi

Koperasi Unit Desa (KUD) Sinarjaya merupakan koperasi peternakan sapi perah dan memiliki unit simpan pinjam. Berdasarkan hasil penelitian ini menunjukkan kinerja koperasi yang relatif belum stabil dan terjadi fluktuasi naik turun dalam kinerja selama periode 2015-2019. Secara khusus penelitian ini menemukan permasalahan dalam manajemen akuntansi dan keuangan koperasi yang ditunjukkan dengan semakin naiknya kinerja keuangan selama periode 2015-2019 yang tidak mengalami fluktuasi menurun.

Temuan penelitian ini memberi bukti bahwa koperasi dikategorikan cukup sehat karena mampu mencapai standar rasio solvabilitas dan profitabilitas minimum yang ditentukan berdasarkan nilai rata-rata yang ditentukan oleh Departemen Perindustrian dan Koperasi Tahun 2009. Temuan tersebut mengindikasikan bahwa proses akuntansi di KUD Sinarjaya belum ada penerapan standar akuntansi koperasi dan pengelolaan pinjaman kepada anggota koperasi yang terstandarisasi. Manajemen perputaran keuangan koperasi kerap melakukan pembelian aset dan pengelolaan simpanan sukarela yang belum optimal. Adapun faktor lain terkait manajemen disebabkan kemampuan SDM koperasi dalam mengelola keuangan dan akuntansi koperasi. Khususnya unit simpan pinjam kurangnya jumlah pegawai yang menangani pinjaman anggota dan kemampuan daya mereka untuk menganalisis kemampuan bayar anggota terhadap pinjaman mereka.

Pada sisi pembagian SHU koperasi yang diterima anggota. Untuk itu, setiap akhir periode koperasi memberikan laporan kepada anggota tentang kinerja pengurus dan SHU yang diperoleh selama periode tersebut. Tabel 2 menyajikan hasil survei penelitian indikator SHU yang diterima anggota koperasi. 
Tabel 2 Jawaban responden tentang SHU koperasi yang diterima anggota

\begin{tabular}{lcccccc}
\hline \multicolumn{1}{c}{ Pertanyaan } & \multicolumn{3}{c}{ Jawaban responden } & \multicolumn{2}{c}{ Total } \\
\cline { 2 - 7 } & Ya & \% & Tidak & \% & N & \% \\
\hline Apakah pembagian SHU sudah sesuai & 105 & 100 & 0 & 0 & 105 & 10 \\
dengan besarnya simpanan anggota & & & & & & 0 \\
pada koperasi? & & & & & & \\
\hline Apakah SHU yang diterima oleh bapak & 60 & 57 & 55 & 43 & 105 & 10 \\
ibu sebagai tambahan penghasilan & & & & & & 0 \\
dalam memenuhi kebutuhan hidup & & & & & & \\
sehari-hari seperti kebutuhan makanan & & & & & & \\
maupun kebutuhan non makanan? & & & & &
\end{tabular}

Faktor-faktor yang mempengaruhi perkembangan koperasi dengan indikator SHU yang diterima oleh anggota, dari pernyataan pertama mengenai pembagian SHU, 100\% dari responden menyatakan bahwa SHU yang diterima anggota sesuai dengan tingkat simpanan anggota pada Koperasi. Menurut pengurus KUD Sinarjaya mengatakan bahwa SHU yang yang dibagikan kepada anggota adalah sebesar $40 \%$ dari jumlah SHU koperasi dengan rincian, $20 \%$ diukur dari partisipasi anggota dalam berbelanja, 20\% dari simpanan anggota. Tujuan dari persentase pemisahan acuan pembagian SHU adalah agar anggota berperan aktif dalam meningkatkan kinerja koperasi melalui berbelanja keperluan peternakan dan berkontribusi dalam peningkatan kinerja keuangan koperasi. SHU yang diterima ini cukup mempengaruhi tingkat pemenuhan ekonomi anggota, hal ini terlihat dari jawaban responden, sebanyak 60\% dari anggota koperasi menyatakan bahwa SHU yang diterima cukup membantu dalam memenuhi kebutuhan hidup.

Pembagian SHU oleh KUD Sinarjaya setiap tahun jumlahnya bervariasi yang ditentukan pada keaktifan anggota dalam menyimpan dan bertransaksi di koperasi. Berdasarkan wawancara dengan anggota koperasi, keaktifan anggota sangat memengaruhi SHU yang mereka terima dan bahkan melebihi pendapatan SHU dari simpanan mereka. Selain itu, SHU sebagai tambahan pemenuhan kebutuhan keluarga seperti sandang dan papan, 
sedangkan untuk kebutuhan makan telah diperoleh dari penghasilan suami atau keluarga. Dengan kata lain, SHU sebagai penghasilan tambahan bagi anggota dan bukan penghasilan utama dari anggota. Seluruh anggota mendapat penghasilan dari penjualan susu yang disetor setiap dua kali sehari. Penghasilan penjualan susu sapi untuk pemenuhan ekonomi sehari-hari.

b. Faktor-faktor SDM Internal Koperasi

Peneliti melakukan wawancara dan pengamatan dilapangan terkait faktor SDM internal koperasi. Penelitian ini menemukan suatu kesenjangan dalam penempatan staf yang tidak sesuai kemampuan mereka. Rerata staf koperasi berpendidikan SMA sederajat. Hal ini mengindikasikan bahwa pengembangan SDM koperasi sangat perlu menjadi perhatian pengurus koperasi. Dalam hal ini kesesuaian dengan fungsi manajemen dan staf belum berjalan secara optimal. Khususnya staf akuntansi melaksanakan proses akuntansi dan pelaporan berdasarkan pencatatan masa lalu. Dengan kata lain, pekerjaan mereka menyesuaikan apa yang telah dilaporkan oleh akuntan koperasi pada periode masa lalu. Oleh karena itu, pembinaan dan pendampingan bagi manajemen untuk membuat Standar Operasional Manajemen untuk perbaikan manajemen mengenai aspek perencanaan dan pengelolaan akuntansi keuangan koperasi. Dengan demikian, fungsi-fungsi perencanaan, dan penilaian kinerja diperlukan untuk mengetahui semua fungsi telah berjalan secara efektif dan efisien (Derfuss, 2015; Fauziah et al., 2017).

Penelitian ini mengkonfirmasi penelitian (Siregar, 2020; Sulistia \& Suparman, 2019) yang membuktikan bahwa pola pembinaan dan pendampingan pada koperasi mempengaruhi kinerja koperasi yang lebih baik. Pendidikan dan pelatihan dalam upaya meningkatkan kompetensi SDM koperasi sebagai cerminan pelaksanaan jati diri koperasi (prinsip koperasi, ekonomi dan partisipasi anggota) akan meningkatkan keberhasilan koperasi. Pengembangan SDM melalui pelatihan, pembinaan dan pendampingan dari universitas dan pemerintah memberikan tambahan daya kompetitif koperasi dengan perusahaan lain. SDM koperasi yang berkompetensi memprioritaskan kepentingan koperasi yang secara umum meningkatkan produktivitas. Pembinaan dan pendampingan SDM yang menjadi objek penelitian ini dalam 
meningkatkan pemahaman akuntansi dan manajemen. Mereka merasakan perubahan secara personal untuk bekerja dengan benar sesuai dengan standar akuntansi dan meningkatkan kepercayaan diri dalam memberikan laporan kepada manajemen dan anggota koperasi secara luas. Bahkan fenomena asal bapak senang dalam tanggung jawab ke pimpinan selama ini tidak menjadi fokus utama para staf dalam bekerja.

Obeservasi strategi pembinaan dan pendampingan pada KUD Sinarjaya dalam meningkatkan kinerja dan pelayanan pengurus koperasi bagi anggota berdampak dalam perbaikan kemampuan staf akuntansi dalam membuat laporan keuangan koperasi. Sebelum pembinaan dan pendampingan, staf akuntansi memiliki kesulitan dalam membuat laporan yang sesuai dengan standar akuntansi dan proses mutasi data keuangan setiap transaksi masih dilakukan secara sederhana. Selain itu, rendahnya pemahaman staf akuntansi mengenai pedoman umum akuntansi perubahan aset, hutang dan modal koperasi sesuai fakta di koperasi. Pembinaan dan pendampingan selama dua minggu memberikan wawasan baru bagi pengurus inti dan staf akuntansi dalam memahami akuntansi koperasi. Penataan laporan keuangan koperasi selama pembinaan dan pendampingan menjadi lebih baik dan dapat dipahami oleh semua anggota koperasi. Hal ini dibuktikan pada saat rapat anggota tahunan (RAT) yang memberikan respon baik atas laporan keuangan dan pertanggung jawaban pengurus ke anggota. Dengan demikian, strategi pembinaan dan pendampingan pada KUD Sinarjaya memberikan dampak baik pada kinerja pengurus dan staf koperasi.

Fokus observasi lainya yang peneliti lakukan adalah tata kelola manajemen koperasi. Sebelum pembinaan dan pendampingan, KUD Sinarjaya tata kolola koperasi masih rendah dalam memberikan pelayanan kepada anggota dan tidak adanya pedoman baku atas transaksi-transaksi koperasi dengan anggota dan non anggota. Pembinaan dan pendampingan yang peneli laksanakan membantu pengurus membuat standar operasional manajemen dalam mengatasi masalah transaksi koperasi yang melibatkan anggota koperasi dan non anggota dalam hubungan bisnis atas penjualan barang atau jasa. Peneliti memberikan evaluasi atas kegiatan pelayanan bisnis dalam 
menetapkan harga pokok penjualan, harga perolehan (harga beli) untuk menghitung pendapatan dalam transaksi dan periode tertentu.

\section{SIMPULAN}

Berdasarkan penelitian ini para pegawai telah diberikan kesempatan untuk meningkatkan pengetahuannya, baik melalui pendidikan formal maupun melalui Pendidikan dan Pelatihan. Proses pembinaan dan pendampingan ini mendorong setiap pegawai untuk meningkatkan pengetahuan, kemampuan dan keterampilan kerja, agar pegawai dapat meningkat dan memiliki semangat yang tinggi dalam mencapai prestasi. Penelitian ini memberikan bukti bahwa pembinaan dan pendampingan bagi SDM koperasi memberikan perubahan dalam proses manajemen. Fokus pembinaan pada proses akuntansi dan pelaporan keuangan menunjukkan staf akuntansi memiliki pemahaman yang benar dalam akuntansi koperasi dan meningkatkan kepercayaan diri untuk menyediakan informasi kepada stakeholder koperasi KUD Sinarjaya. Temuan penelitian menunjukkan bahwa pembinaan dalam pendidikan dan organisasi bisnis memberikan manfaat yang signifikan seperti memastikan struktur organisasi yang lebih kompetitif dan efisien, meningkatkan motivasi karyawan dan memperkuat kapasitas karyawan untuk bekerja sebagai tim.

Agar strategi pemberdayaan koperasi KUD Sinarjaya dapat lebih mendukung ketahanan ekonomi keluarga anggotanya, maka disarankan kepada koperasi untuk meningkatkan kerjasama dengan pihak ketiga yaitu universitas dan perbankan dalam pelayanan kepada anggota sebagai salah satu faktor yang mempengaruhi perkembangan koperasi dapat dirasakan baik pengaruhnya terhadap ketahanan ekonomi keluarga. Selain itu, koperasi lebih banyak melibatkan anggota untuk join bisnis dengan koperasi, dan memberikan kesempatan yang besar bagi anggotanya untuk ikut berwirausaha bersama koperasi, sehingga anggota tidak hanya sebagai konsumen saja akan tetapi juga sebagai pelaku usaha. Terakhir, hubungan dengan universitas dalam program pendampingan dan pembinaan tidak hanya dilakukan satu perioda, namun seyogyanya dilaksanakan secara rutin terus menerus untuk meningkatkan kompetensi maupun pengetahuan tentang koperasi untuk pengurus dan anggota koperasi secara rutin. 


\section{DAFTAR RUJUKAN}

Adam Roubitchek. (2018). Understanding The Use Of Instructional Coaching To Support Cooperative Learning In The Secondary Classroom. Dissertation, Secondary Education and Teaching Commons. https://digitalcommons.olivet.edu/edd_diss/114

Castilla-Polo, F., \& Sánchez-Hernández, M. I. (2020). Cooperatives and sustainable development: A multilevel approach based on intangible assets. Sustainability (Switzerland), 12(10). https://doi.org/10.3390/su12104099

Creswell, J., \& Plano Clark. (2011). Designing and conducting mixed methods research (C. S. ThousandOaks (ed.); 2nd ed).

Derfuss, K. (2015). Relating Context Variables to Participative Budgeting and Evaluative Use of Performance Measures: A Meta-analysis. Abacus, 51(2), 238-278. https://doi.org/10.1111/abac.12046

Fauziah, A., Ramlan, N., Khairul Azman, M. S., Lutfan, J., Zahrul Akmal, D., Harliana, H., Sharifah Khadijah, S. A. B., \& Shakila, A. (2017). Applying Empowerment Approach In Community Development. Jurnal Universiti Tun Hussein Onn Malaysia, Johor, Malaysia, November, 509. https://jurnal.umj.ac.id/index.php/icss/article/view/2359

Harelimana, J. B. (2020). Contribution of Cooperatives to Social-Economic Development in Rwanda. Open Access Journal of Biogeneric Science and Research, 1(3), 1-5. https://doi.org/10.46718/jbgsr.2020.01.000017

Kilburg, R. R. (2000). Coaching:, Executive Chaos, Developing Managerial Wisdom in a World of (American Psychological Association (ed.)). Washington.

My Coop. (2017). Strengthening Management Capacities Of Agricultural. The International Labour Organization (ILO) and Agriterra.

Nasution, C., \& Thamrin. (2016). Implementasi Kebijakan Program Pembinaan Dinas Sosial Dan Tenaga Kerja Terhadap Gelandangan Dan Pengemis Di Kota Medan. Jurnal Administrasi Publik Universitas Medan Area, 4(2), 105-119. Siregar, A. P. (2020). Kinerja Koperasi Di Indonesia. Vigor: Jurnal Ilmu Pertanian Tropika Dan Subtropika, 511-38. 
14 | Jurnal Pendidikan dan Kewirausahaan Vol. 9 No. 12021

https://doi.org/10.31002/vigor.v5i1.2416

Sugiyono. (2018). Metode Penelitian Kuantitatif, Kualitatif dan R\&D (Alpabeta (ed.)).

Sulistia, D. F., \& Suparman, N. (2019). Peranan Pembinaan Dinas Koperasi Dan Usaha Kecil Jawa Barat Dalam Memajukan Perkoperasian Di Daerah. Publikauma: Jurnal Administrasi Publik Universitas Medan Area, 7(2), 58. https://doi.org/10.31289/publika.v7i2.2818

Taremwa, N. K., \& Lopoyetum, S. K. (2015). The Role Of Academic And Training Institutions In Cooperatives Development. East African Journal of Science and Technology, 5(1), 196-207.

Velmonte, G. (2020). Contributions of Cooperatives to the Economic Development. An International Multidisciplinary Double-Blind Peer-Reviewed Research Journal, December.

Wilson, C. (2007). Best Practice in Performance Coaching: A Handbook for Leaders, Coaches, HR Professionals and Organizations (Kogan Page).

Wisdom, J., \& Creswell, J. W. (2013). Integrating quantitative and qualitative data collection and analysis while studying patient-centered medical home models. Agency for Healthcare Reseach and Quality, 13-0028-EF, 1-5. https://doi.org/No. 13-0028-EF.

Yirci, R., Karakose, T., \& Kocabas, I. (2016). Coaching as a continuous improvement tool. Journal of Education and Practice, 17(13), 4,74.

Zulhartati, S. (2010). Peranan Koperasi Dalam Perekonomian Indonesia. Jurnal Pengabdian Masyarakat. Guru Membangun, 25(3), 463-466. 